\title{
Microstructure and wear resistance of laser-melted TiC reinforced nickel aluminide dual-phase matrix in situ composite
}

\author{
Y. Chen ${ }^{\mathrm{a}, \mathrm{b}}$, H.M. Wang ${ }^{\mathrm{b}, *}$ \\ ${ }^{\mathrm{a}}$ Laboratory of Laser Intelligent Manufacturing, Institute of Mechanics, Chinese Academy of Sciences, \\ 15 Beisihuanxi Road, Beijing 100080, People's Republic of China \\ ${ }^{\mathrm{b}}$ Laboratory of Laser Materials Processing and Surface Engineering, School of Materials Science and Engineering, \\ Beihang University 37, XueYuan Road, Beijing 100083, People's Republic of China
}

Received 1 February 2005; accepted 27 June 2005

Available online 22 September 2005

\begin{abstract}
A laser-melted TiC-reinforced nickel aluminide matrix in situ composite was fabricated. The composite consisted of well-developed TiC dendrites and a $\left(\mathrm{NiAl}-\mathrm{Ni}_{3} \mathrm{Al}\right)$ dual-phase matrix. The microstructure of the laser-melted in situ composite was characterized by optical microscopy (OM), scanning electron microscopy (SEM), transmission electron microscopy (TEM) and X-ray diffraction (XRD). Results show that the $\mathrm{TiC} /\left(\mathrm{NiAl}-\mathrm{Ni}_{3} \mathrm{Al}\right)$ composite has excellent wear resistance for both room- and high-temperature sliding wear test conditions. (C) 2005 Elsevier Ltd. All rights reserved.
\end{abstract}

Keywords: A. Nickel aluminides; A. Composites; C. Laser processing; G. Wear-resistant applications

\section{Introduction}

Nickel aluminides based on $\mathrm{NiAl}$ and $\mathrm{Ni}_{3} \mathrm{Al}$ are expected to be promising structural materials due to their high melting point, low density and high specific modulus $[1,2]$. Of the two nickel aluminides, $\mathrm{NiAl}$ alloy has a higher melting point $\left(1638^{\circ} \mathrm{C}\right)$ than $\mathrm{Ni}_{3} \mathrm{Al}$, but possesses lower ductility and fracture toughness at room temperature [3-5]. $\mathrm{Ni}_{3} \mathrm{Al}$ is also well-known for its strong abnormal yield strength-temperature relationship, which is of great benefit for applications at elevated temperature. However, shortcomings such as low ambient temperature ductility and poor fracture toughness, as well as inadequate elevated temperature strength, prevent $\mathrm{NiAl}$ from being used for practical applications. Recently, several studies have attempted to improve the ambient temperature ductility of nickel aluminides by micro- and macro-alloying $[3,6,7]$.

\footnotetext{
* Corresponding author. Address: Laboratory of Laser Materials Processing and Surface Engineering, School of Materials Science and Engineering, Brihang University, 37 Xueynan Road, Beijing 100083, People's Republic of China. Tel.: +86 106265 1165; fax: +86 106252 1859.

E-mail address: wanghum@buaa.edu.cn (H.M. Wang).
}

0966-9795/\$ - see front matter (C) 2005 Elsevier Ltd. All rights reserved. doi:10.1016/j.intermet.2005.06.011
Concerning nickel aluminide elevated temperature strength, one possible approach is to incorporate metallurgically stable, hard and fine ceramic particles [8-11]. It is well known that the MC-type carbides (e.g. TiC) have the advantages of high hardness, high melting point, low density and excellent high-temperature stability, and therefore, are expected to be suitable reinforcements in nickel aluminides. Considering both the good oxidation resistance of $\mathrm{NiAl}$ and the excellent high-temperature strength of $\mathrm{Ni}_{3} \mathrm{Al}, \mathrm{TiC}$ reinforced in situ composites with a nickel aluminide dual-phase matrix are expected to be candidate structural materials for elevated temperature applications. From a tribological point of view, such composites are expected to possess excellent abrasive wear resistance due to the high hardness of TiC. Meanwhile, the strong atomic bonding and relatively high hardness of nickel aluminide make deformation difficult during contact with mating metallic materials, and therefore, such composites are also expected to exhibit good adhesive wear resistance. Fabrication processing approaches of nickel aluminide matrix composites include simultaneous combustion and densification synthesis [12], solid-state reaction by mechanical alloying [13], self-propagating high-temperature synthesis $[14,15]$, high temperature and high densification in situ synthesis [16], etc. To eliminate the influence of ceramic inclusions from the refractory 


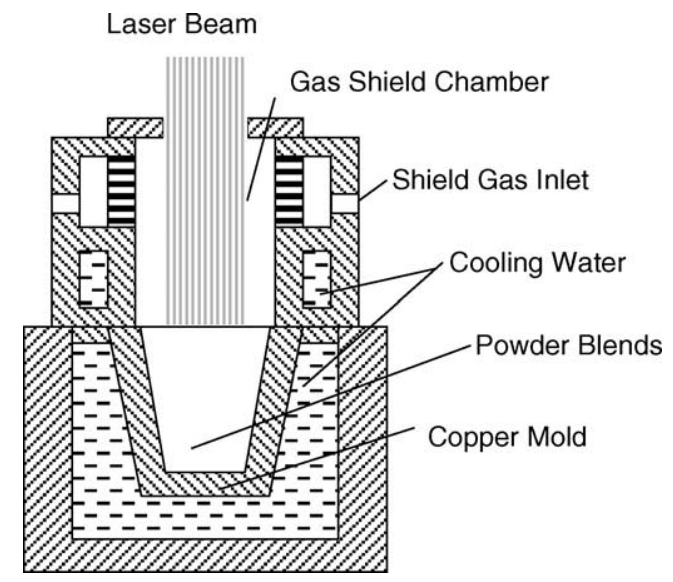

Fig. 1. Schematic illustration of the water-cooled copper-mold laser-melting furnace [17].

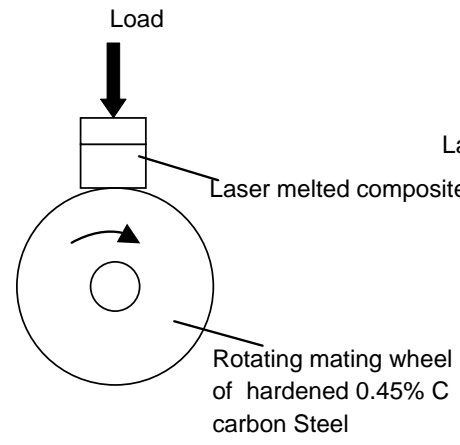

(a)

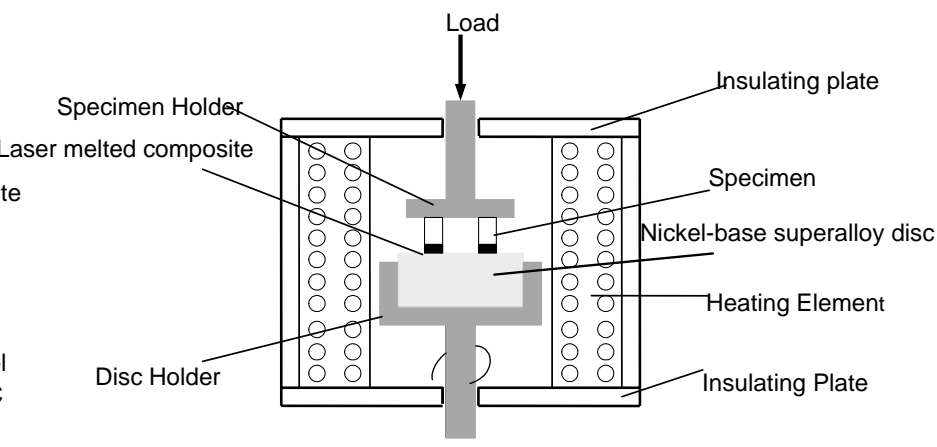

(b)

Fig. 2. Schematic illustrations of (a) the block-on-wheel sliding wear tester and (b) the high-temperature pin-on-disc sliding wear tester.

crucible on these composites and to obtain composites with a fine and dense microstructure, TiC reinforced in situ composite with nickel aluminide dual-phase matrix was fabricated by the lasmelt ${ }^{\mathrm{TM}}$ process [17], using a newly developed chilled copper-mold laser melting furnace. The microstructure of the laser-melted composite was characterized by optical microscopy (OM), scanning electron microscopy (SEM), transmission electron microscopy (TEM) and X-ray diffraction (XRD). The room- and high-temperature sliding wear resistance was evaluated and the wear mechanisms were determined.

\section{Experimental procedures}

Commercially pure $\mathrm{Ni}, \mathrm{Al}, \mathrm{Ti}$ and $\mathrm{C}$ powders with an average particle size ranging from 4.5 to $7.5 \mu \mathrm{m}$ were selected as starting precursor materials for fabricating TiCreinforced in situ composites with a nickel aluminide matrix by the laser melting technique. Elemental powder blends with a composition of Ni-17.5Al-15Ti-15C (at.\%) were mixed prior to laser processing. As schematically illustrated in Fig. 1, the Ni-Al-Ti-C elemental powder blends were placed in a water-cooled copper-mold, using Ar as a shielding atmosphere, and were melted under the irradiation of a high power $\mathrm{CO}_{2}$ laser beam. The laser melting was performed with a $5 \mathrm{~kW} \mathrm{CO}$ laser equipped with a four-axis computer numerical-controlled (CNC) work table. The laser melting processing parameters were: laser output power $2.5 \mathrm{~kW}$, laser beam diameter $7 \mathrm{~mm}$, and laser irradiation time $20-30 \mathrm{~s}$.

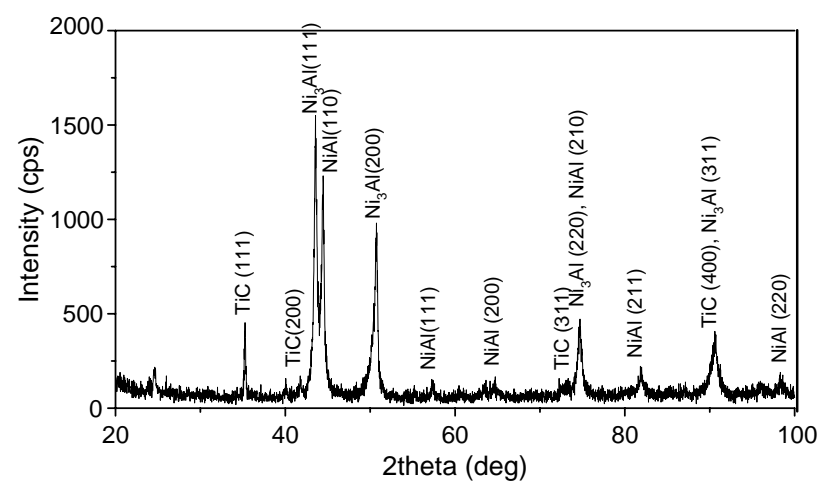

Fig. 3. Results of XRD analysis of a laser melted in situ composite with $\mathrm{Ni}-$ Al-Ti-C powder blends. 

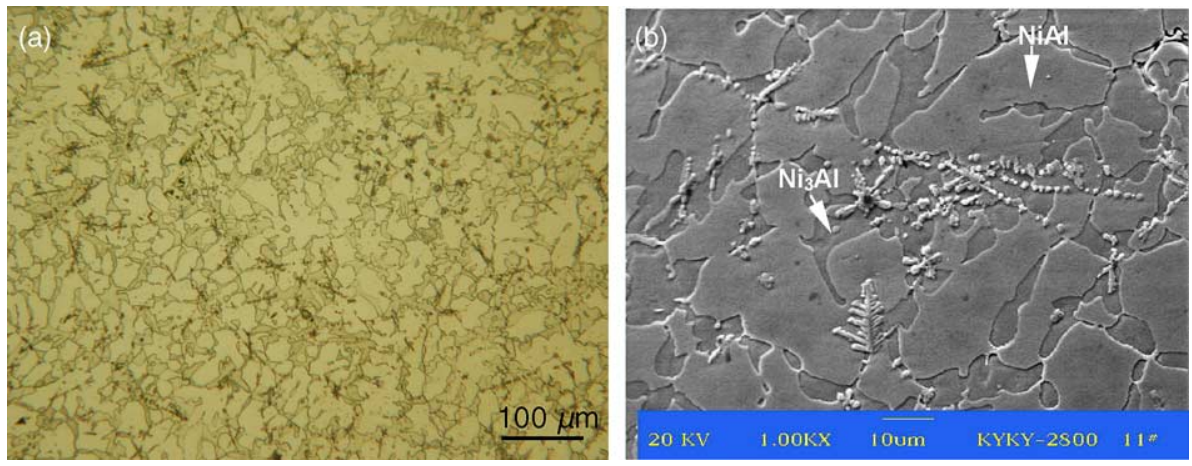

Fig. 4. OM micrograph (a) and SEM micrograph (b) showing the typical microstructure of laser melted in situ composite with composition (at.\%) of Ni$17.5 \mathrm{Al}-15 \mathrm{Ti}-15 \mathrm{C}$.

Samples of laser-melted in situ composite were prepared for microstructure observation by standard metallographic polishing techniques and were etched in a solution of $25 \mathrm{vol} \%$ nitric acid +50 vol $\%$ hydrofluoric acid +25 vol $\%$ glycerin. The microstructure of the laser-melted composite was characterized using optical microscopy (OM), scanning electron microscopy (SEM) with EDS, and transmission electron microscope (TEM). The constitutional phases were identified by X-ray diffraction (XRD) using a $\mathrm{Cu} \mathrm{K}_{\alpha}$ radiation at a voltage of $40 \mathrm{kV}$, a current of $40 \mathrm{~mA}$ and a scanning rate of $5 \% \mathrm{~min}$. Thin specimens for TEM observation were cut from laser-melted ingots and mechanically thinned to $40 \mu \mathrm{m}$ before final thinning by $\mathrm{Ar}$ ion bombardment. Microhardness was determined using a Vicker tester with a test load of $200 \mathrm{~g}$ and a dwell time of $15 \mathrm{~s}$.

Dry sliding wear tests were conducted on a MM200 block-on-wheel wear tester at room-temperature with an
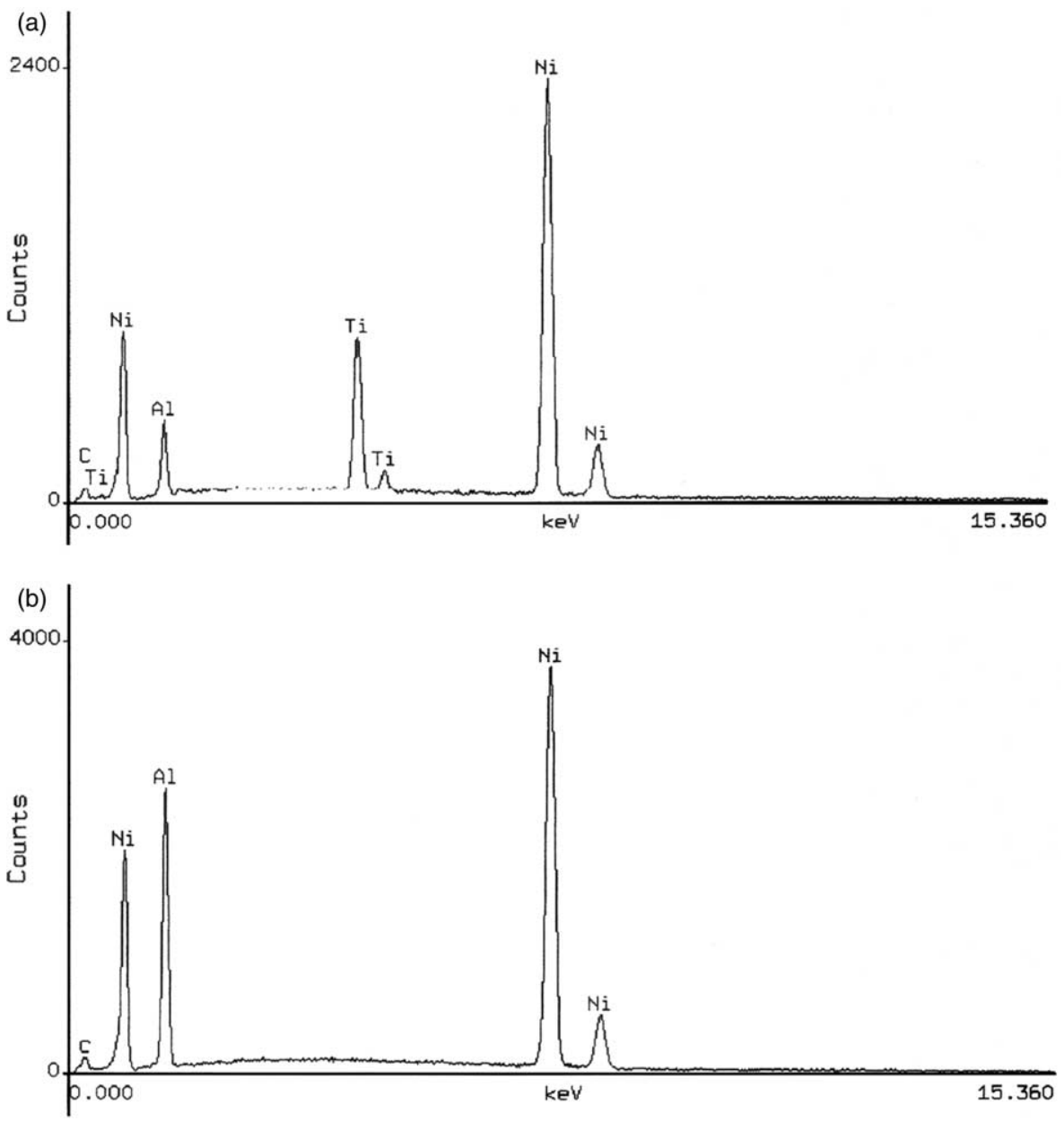

Fig. 5. EDS results of $\mathrm{Ni}_{3} \mathrm{Al}$ (a) and $\mathrm{NiAl}(\mathrm{b})$. 

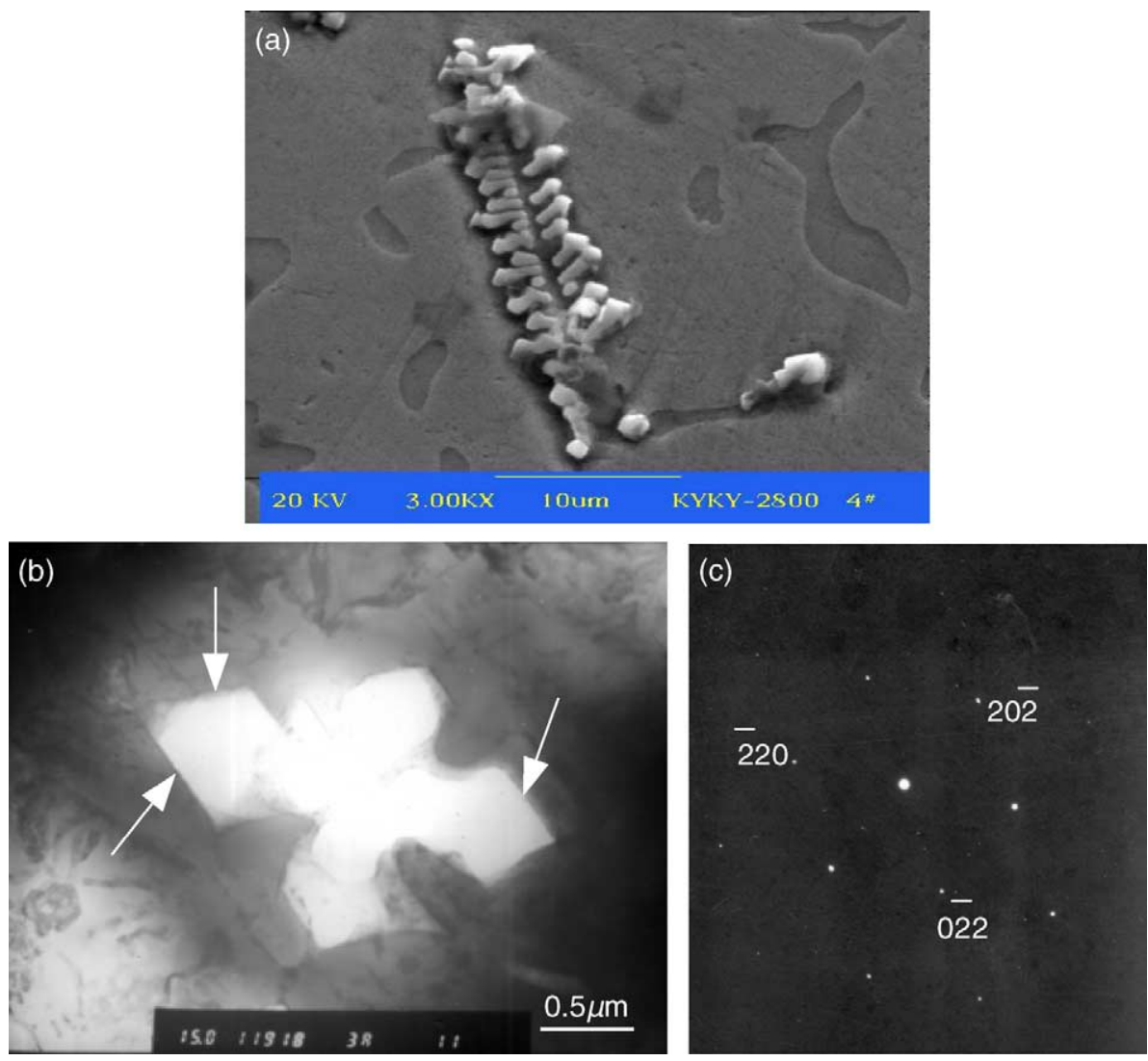

Fig. 6. SEM image (a), TEM image (b) showing the typical growth morphology of TiC and SAD pattern of TiC.

applied test load of $98 \mathrm{~N}$, relative sliding speed of $0.42 \mathrm{~m} / \mathrm{s}$ and sliding distance of $3020 \mathrm{~m}$. This is schematically illustrated in Fig. 2a. A cube specimen, $10 \mathrm{~mm} \times 10 \mathrm{~mm} \times$ $10 \mathrm{~mm}$, slides on a rotating hardened $0.45 \% \mathrm{C}$ steel ring (Vicker hardness of 560). Wear specimen preparation consisted of grinding and polishing the cube prior to wear testing. To guarantee consistent wear test result, each specimen was matched to a wheel counterpart. The friction vs. time curves were recorded and the friction coefficient was calculated. High-temperature wear resistance of the laser-melted TiC-reinforced composite was measured on a pin-on-disc high-temperature sliding wear tester (as schematically illustrated in Fig. 2b) at 400 and $600{ }^{\circ} \mathrm{C}$ in air. For this wear test, two laser-melted specimens, $6 \mathrm{~mm} \times$ $6 \mathrm{~mm} \times 6 \mathrm{~mm}$, slide on the surface of the rotating disc made of a solid-solution strengthened Nimonic 750. The test parameters were: load $98 \mathrm{~N}$, sliding velocity $0.1 \mathrm{~m} / \mathrm{s}$ and the total wear sliding distance $180 \mathrm{~m}$. Before and after the wear tests, the pin-on-block specimens were cleaned in acetone and the mass loss was measured using a precision electronic balance (Sartorius BS110) with an accuracy of $0.1 \mathrm{mg}$. Standard solution-treated AISI321SS was selected as the reference material for all the wear tests. The relative wear resistance, i.e. the ratio of mass loss of the AISI321SS specimen to that of laser processed composite specimen, was used to rank the wear resistance for the room- and high-temperature sliding wear test conditions. The worn surfaces and wear debris were examined using SEM.

\section{Results}

XRD results of the laser-melted composite are shown in Fig. 3.The main constitutional phases of the laser melted $\mathrm{Ni}-\mathrm{Al}-\mathrm{Ti}-\mathrm{C}$ powder blends are $\mathrm{TiC}, \mathrm{NiAl}$ and $\mathrm{Ni}_{3} \mathrm{Al}$. As indicated in Fig. 4, the laser-melted composite is free from microcracks and pores, and has a uniform and dense microstructure consisting of $\mathrm{TiC}$ uniformly distributed in the $\mathrm{NiAl}-\mathrm{Ni}_{3} \mathrm{Al}$ dual-phase matrix. Because of the rapid heat conduction cooling of the water-chilled copper mold, a fine microstructure results. Also, the EDS results of $\mathrm{Ni}_{3} \mathrm{Al}$ and $\mathrm{NiAl}$ are shown, respectively, in Fig. 5a and b.

The growth morphology of the $\mathrm{TiC}$ occurs as welldeveloped dendrites, as shown in Fig. 6a. Moreover, the advancing fronts of the $\mathrm{TiC}$ dendrites are faceted, as

Table 1

Table1 Microhardness test results of laser-melted $\mathrm{TiC} /\left(\mathrm{NiAl}-\mathrm{Ni}_{3} \mathrm{Al}\right)$ composite

\begin{tabular}{llllll}
\hline & 1 & 2 & 3 & 4 & 5 \\
\hline $\begin{array}{l}\text { Microhardness } \\
(\mathrm{HV})\end{array}$ & 646 & 637 & 641 & 652 & 647 \\
\hline
\end{tabular}



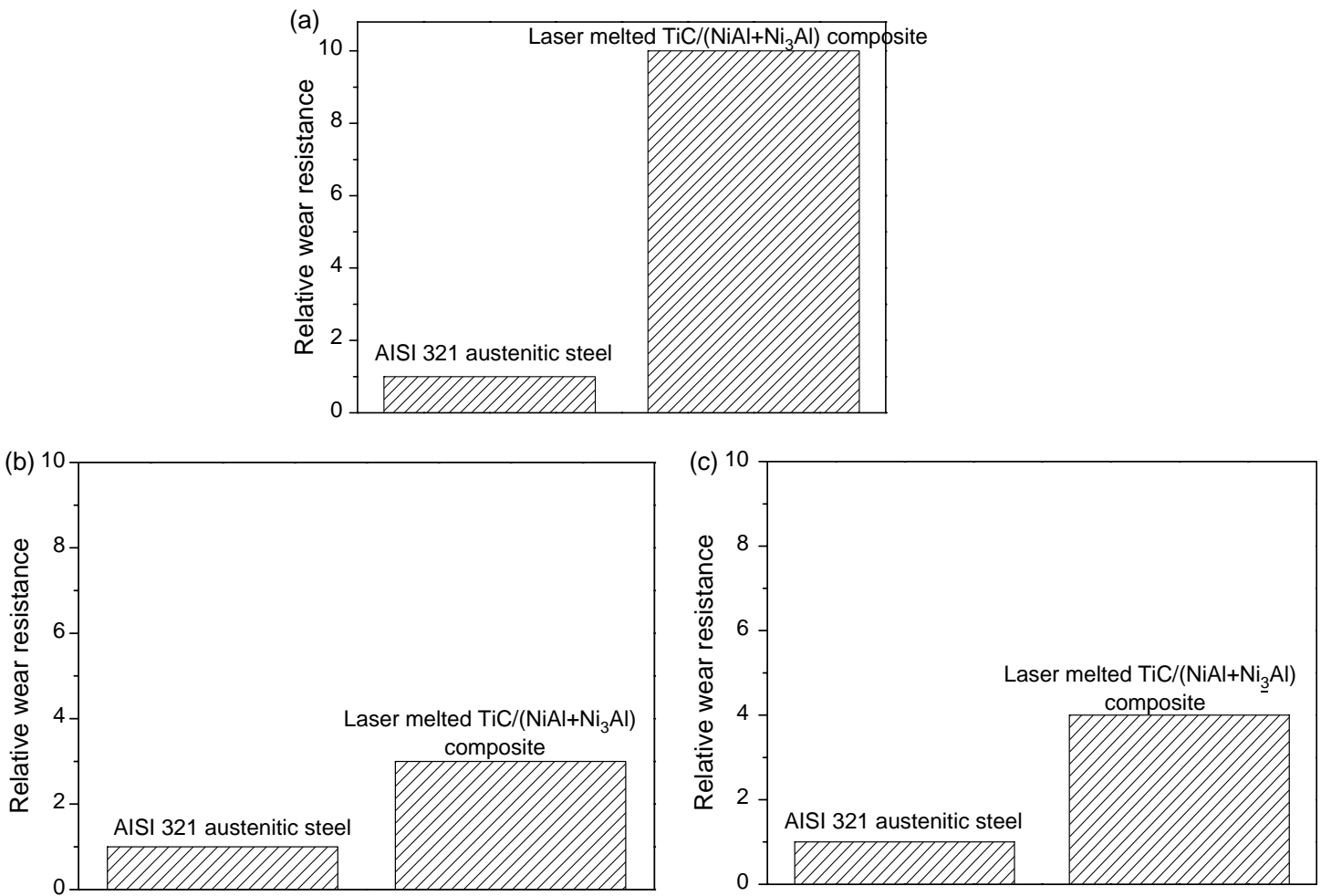

Fig. 7. Relative wear resistance of the laser-melted $\mathrm{TiC} /\left(\mathrm{NiAl}-\mathrm{Ni}_{3} \mathrm{Al}\right)$ composite under room-temperature dry sliding (a), under 400 (b) and $600{ }^{\circ} \mathrm{C}(\mathrm{c})$ sliding wear test conditions.

indicated in the arrows in Fig. 6b, illustrating clearly that it grows by lateral growth. Selected area electron diffraction (SAD) shows that the TiC has an fcc crystalline structure, as shown in Fig. 6(c). The calculated lattice pattern of $\mathrm{TiC}$ carbide is approximately $0.4334 \mathrm{~nm}$, which is slightly higher than the standard lattice parameter, $0.4328 \mathrm{~nm}$.

Table 1 shows the microhardness test results. Five points throughout the $\mathrm{TiC} /\left(\mathrm{NiAl}-\mathrm{Ni}_{3} \mathrm{Al}\right)$ matrix were measured.
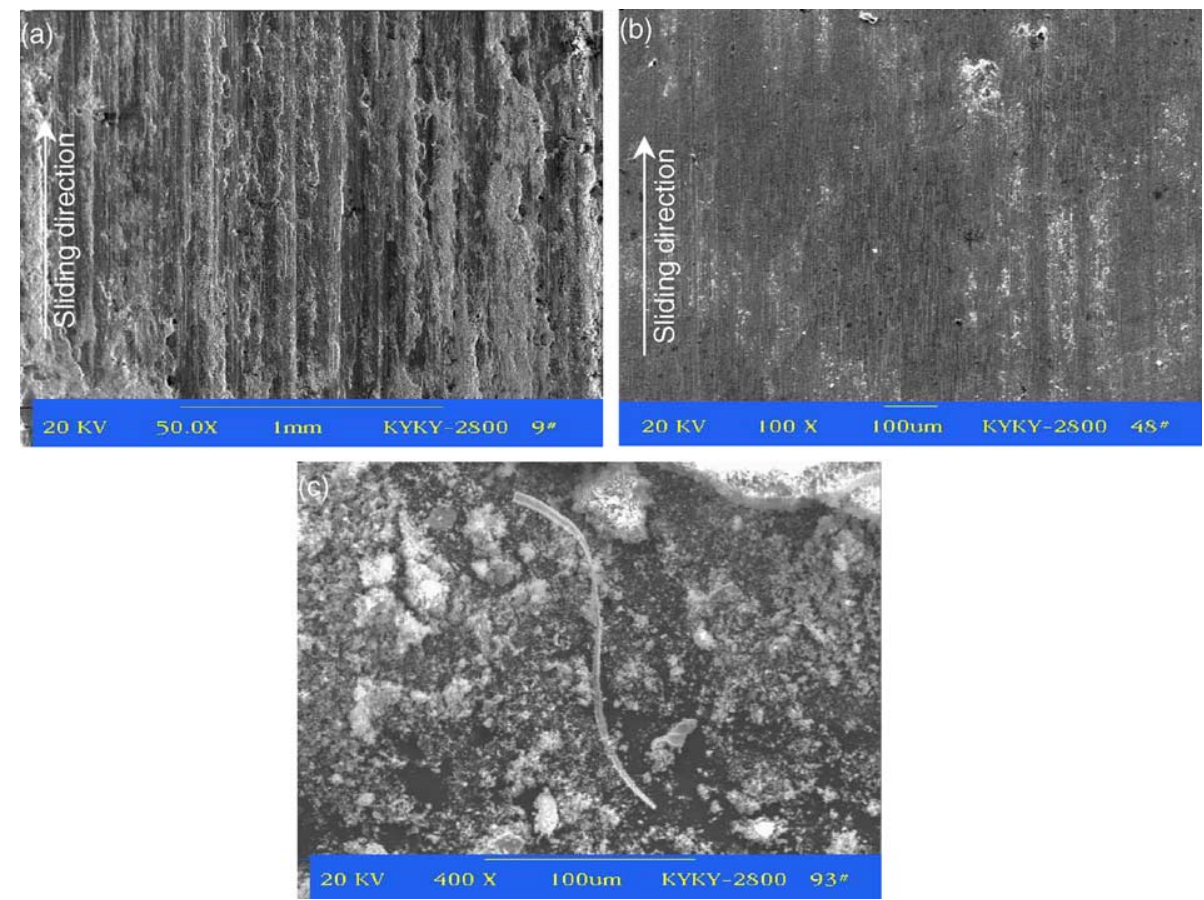

Fig. 8. SEM micrographs showing the worn surface morphologies of the AISI321 austenitic stainless steel (a), laser-melted TiC/(NiAl-Ni $3 \mathrm{Al})$ composite (b) and wear debris (c) under room-temperature sliding wear test conditions. 


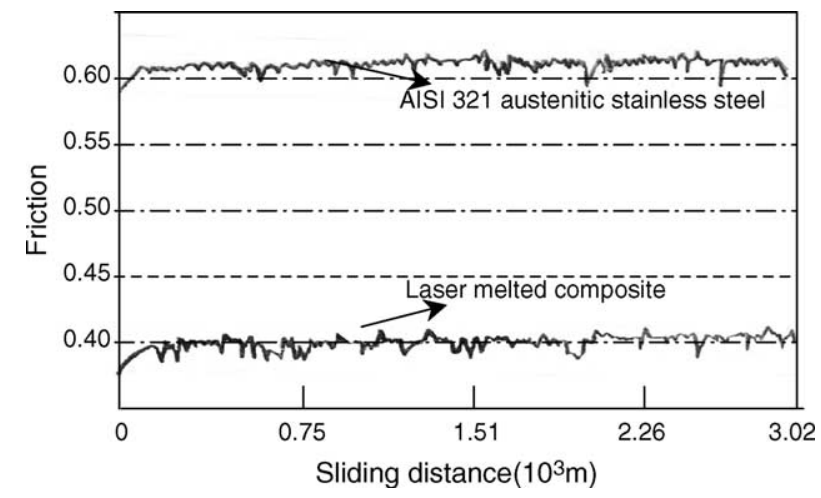

Fig. 9. Variation of friction coefficient vs. sliding distance (applied load of $98 \mathrm{~N}$ and sliding velocity of $0.42 \mathrm{~m} / \mathrm{s}$ ).

Because of the presence of $\mathrm{TiC}$ and the fine microstructure of $\left(\mathrm{NiAl}-\mathrm{Ni}_{3} \mathrm{Al}\right)$ dual-phase matrix, the laser-melted composite has a high hardness with an average value of HV640.

In comparison to the AISI321SS, the wear resistance of the laser-melted composite is enhanced by a factor of 10 under room temperature dry sliding wear test conditions, as indicated in Fig. 7a. Under sliding wear test conditions at $400{ }^{\circ} \mathrm{C}$, wear resistance of the composite is three times that of AISI321SS (Fig. 7b). At $600^{\circ} \mathrm{C}$, the wear resistance of the composite is approximately four times that of AISI321SS (Fig. 7c).

\section{Discussion}

It is well known that TiC-type $\mathrm{MC}$ carbide has both high melting point $\left(3200^{\circ} \mathrm{C}\right)$ and a large negative free energy of formation in the $\mathrm{Ni}-\mathrm{Al}-\mathrm{Ti}-\mathrm{C}$ system, and therefore, $\mathrm{TiC}$ might precipitate from the liquid as the primary phase and grow freely as a dendrite. As the temperature of the residual liquid decreases, $\mathrm{NiAl}$ precipitates following the solidification of $\mathrm{TiC}$, because $\mathrm{Ni}$ and $\mathrm{Al}$ can be solutionized in the primary $\mathrm{TiC}$ dendrites. Then, the peritectic reaction $\mathrm{L}+$ $\mathrm{NiAl} \rightarrow \mathrm{Ni}_{3} \mathrm{Al}$ occurs. However, the peritectic reaction cannot proceed completely and the final peritectic products are $\mathrm{NiAl}$ and $\mathrm{Ni}_{3} \mathrm{Al}$. Consequently, the nominal chemical composition of residual liquid deviates from that of peritectic point, leading to a $\mathrm{NiAl}-\mathrm{Ni}_{3} \mathrm{Al}$ dual-phase matrix composite.

By comparing Fig. 8a with Fig. 8b, it is clearly seen that the worn surface of the AISI321SS is very rough with deformation and adhesion features. The worn surface of the laser-melted $\mathrm{TiC} /\left(\mathrm{NiAl}-\mathrm{Ni}_{3} \mathrm{Al}\right)$ composite is relatively smooth with only minor scratching and little adhesion. As shown in Fig. 8c, the morphologies of wear debris are mainly small-flake-like, ribbon-like and powder-agglomerates. Moreover, further EDS analysis shows that debris are highly enriched in Fe, illustrating that they are detached mainly from hardened $0.45 \%$ steel counterpart. The friction coefficient of laser-melted $\mathrm{TiC} /\left(\mathrm{NiAl}-\mathrm{Ni}_{3} \mathrm{Al}\right)$ composite is also considerably lower than that of the AISI321SS, as indicated in Fig. 9.

Wear surfaces of AISI321SS tested in high-temperature sliding are extremely rough with large and deep wear grooves and adhesive wear features, as shown in Fig. 10a and b. The worn surface of the $\mathrm{TiC} /\left(\mathrm{NiAl}-\mathrm{Ni}_{3} \mathrm{Al}\right)$ composite tested at $400{ }^{\circ} \mathrm{C}$ sliding wear conditions is relatively smooth with few adhesive wear features (Fig. 10c). It is worth noting that
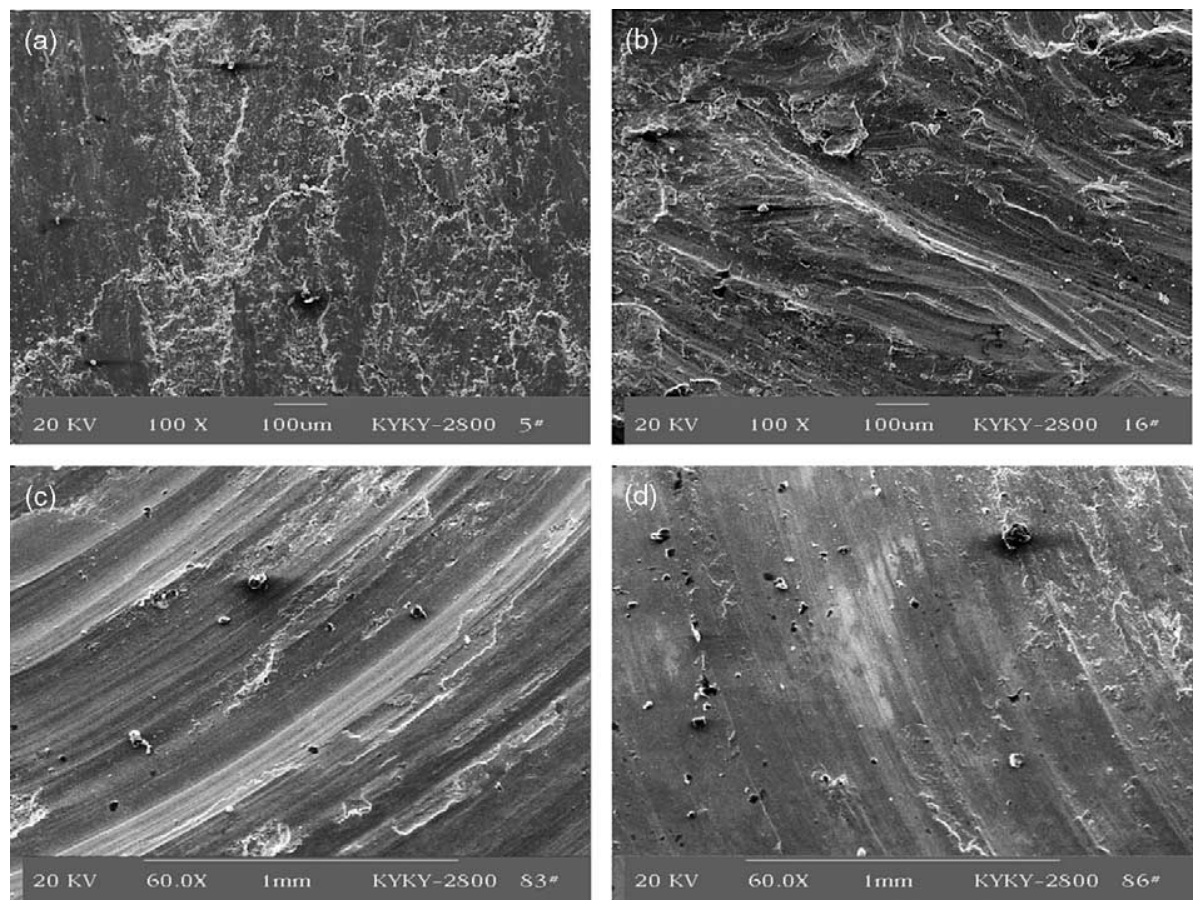

Fig. 10. SEM micrographs showing the worn surface morphologies of AISI321 austenitic stainless steel (a) 400 , (b) $600{ }^{\circ} \mathrm{C}$ and the laser-melted TiC-reinforced composite, (c) 400 and (d) $600{ }^{\circ} \mathrm{C}$ (applied load of $98 \mathrm{~N}$ and sliding velocity of $0.1 \mathrm{~m} / \mathrm{s}$ ), 
the worn surface of the $\mathrm{TiC} /\left(\mathrm{NiAl}-\mathrm{Ni}_{3} \mathrm{Al}\right)$ composite tested at $600{ }^{\circ} \mathrm{C}$ is very smooth with no appreciable grooving or adhesive characteristics, as shown in Fig. 10d.

TiC is well-known for its high hardness, high melting point and excellent high-temperature stability, and the dendritic TiC in the composite plays a dominant role in resisting abrasive wear. When metallic surfaces are in contact during dry sliding wear, the local temperature at the contact points of the surface is high, and the hardness near these points quickly decreases. As a result, serious plastic deformation, local contact-welding between the contacting asperities, and materials transfer lead to serious material removal from the friction surface as 'patchlike' or 'thin flake-like' wear debris. Because of the high average hardness of the composite (HV640) and the abnormal strength-temperature relationship of $\mathrm{Ni}_{3} \mathrm{Al}$, the laser-melted $\mathrm{TiC} /\left(\mathrm{NiAl}-\mathrm{Ni}_{3} \mathrm{Al}\right)$ composite has the capability to resist micro-cutting, micro-plowing, and repeated surface plastic deformation. As such, it exhibits excellent abrasive wear resistance when sliding against a metallic counterpart. On the other hand, the unique strong atomic bonds of nickel aluminides impart the composite excellent resistance to metallic adhesion and local contact plastic deformationinduced cold-welding, junction formation, and material transfer at the contacting asperities are minimized. Evidence for this is seen by the relatively smooth worn surface and lower coefficient of friction for the composite compared to the AISI321SS. Meanwhile, the abnormal strength-temperature relationship of $\mathrm{Ni}_{3} \mathrm{Al}$ improves the resistance of the composite to plastic deformation at elevated temperature $\left(600-900{ }^{\circ} \mathrm{C}\right)$. In summary, the combination of high hardness and excellent high-temperature stability of $\mathrm{TiC}$ and the strong atomic bonds of the nickel aluminides makes the laser-melted $\mathrm{TiC} /(\mathrm{NiAl}-$ $\mathrm{Ni}_{3} \mathrm{Al}$ ) composite an excellent wear-resistant material for both room- and high-temperature sliding wear test conditions.

\section{Conclusions}

An in situ composite reinforced with $\mathrm{TiC}$ was produced by a laser melting $\mathrm{Ni}-\mathrm{Al}-\mathrm{Ti}-\mathrm{C}$ elemental powders.
The laser-melted $\mathrm{TiC} /\left(\mathrm{Ni}_{3} \mathrm{Al}-\mathrm{NiAl}\right)$ composites possessed a fine microstructure consisting of primary well-developed $\mathrm{TiC}$ dendrite and a $\left(\mathrm{NiAl}-\mathrm{Ni}_{3} \mathrm{Al}\right)$ dual-phase matrix. The combination of high hardness and excellent high-temperature stability of $\mathrm{TiC}$, combined with the strong atomic bonds of the nickel aluminides, makes the laser-melted $\mathrm{TiC} /(-$ $\mathrm{NiAl}-\mathrm{Ni}_{3} \mathrm{Al}$ ) composite an excellent wear-resistant material for room- and high-temperature sliding wear test conditions.

\section{Acknowledgements}

The authors would like to acknowledge the financial support of the National Natural Science Foundation of China (Grant No. 59971003).

\section{References}

[1] Noebe RD, Bowman RR, Nathal NV. Int Mater Rev 1993;38:193.

[2] Miracle DB. Acta Metall Mater 1993;41:64.

[3] Bowman RR, Misra AK, Arnold SM. Metall Trans A 1995;26:615.

[4] Liu CY, Jeng SM, Yang JM, Amato RA. Mater Sci Eng A 1995;191: 149.

[5] Chiu HP, Yang JM, Amato RA. Mater Sci Eng A 1995;203:81.

[6] Liu CY, Jeng SM, Yang JM, Aaato RA. Mater Sci Eng A 1995;149: 49.

[7] Liu CT, White CL, Horton JA. Acta Metall 1985;33:213.

[8] Jha C, Ray R, Whittenberger JD. Mater Sci Eng A 1989;19:109.

[9] Kumar S, Whittenberger JD. Mater Sci Technol 1992;4(8):317.

[10] Wang L, Arsenault RJ. Metall Trans A 1991;22:3013.

[11] Xing ZP, Dai JY, Guo JT, An GY, Hu ZQ. Scripta Mater 1994;31: 1141.

[12] Dunmead SD, Munir ZA, Holt JB, Kingman DD. J Mater Sci 1991;26: 2410.

[13] Krivoroutchko K, Kulik T, Matyja H, Portnoy VK, Fadeeva VI. J Alloys Comp 2000;308:230.

[14] Mei BC, Fu ZY, Wang WM, Yuan RZ. Acta Metall Sinica 1996;32: 1107 [in Chinese].

[15] Mei BC, Yuan RZ. J Chinese Ceram Soc 1994;22:168 [in Chinese].

[16] Liu HZ, Wang AM, Wang LH, Ding BZ, Hu ZQ. Acta Metall Sinica 1997;33:638 [in Chinese].

[17] Wang HM, Luan DY, Zhang LY. Scripta Mater 2003;48:1179. 